\title{
The number of episodes and duration of current IUD use and the risk of ectopic pregnancy
}

Bastaman Basuki

\begin{abstract}
Abstrak
Sebagai salah satu bagian penelitian kasus-kontrol mengenai risiko kehamilan ektopik terganggu (KET), tulisan ini menganalisis pengaruh alat kontrasepsi dalam rahim (AKDR) yang masih dipakai pada saat konsepsi diperkirakan terjadi terhadap risiko KET dibandingkan dengan wanita hamil yang tidak memakai kontrasepsi. Penelitian dilakukan di II kota di Indonesia pada tahun I989/1990. Kasus adalah 560 wanita dengan KET yang mendapat perawatan di rumah sakit dan dikonfirmasikan berdasarkan pemeriksaan histopatologik. Untuk setiap kasus KET diambil seorang kontrol wanita yang masih menikah dan secara klinis hamil yang dipadankan menurut daerah kerja penelitian dan usia dalam batas interval umur lima tahunan. Wawancara dilakukan untuk memperoleh data mengenai karakteristik demografik, metode kontrasepsi yang dipakai, dan riwayat obstetrik-ginekologik. Kasus KET dan kontrol yang pada saat perkiraan konsepsi terjadi masih memakai IUD juga diikutsertakan dalam analisis ini, dan diperoleh 510 KET serta 519 kontrol. Relatif terhadap yang tidak memakai kontrasepsi, pemakai AKDR selama 36-108 bulan mempunyai risiko KET I4 kali lipat [ rctsio odds $(O R)$ suaian $=14,11 ; 95 \%$ interval kepercayaan $(C I)=3,26-61,06]$, dan di antara para pemakai $A K D R$ satu kali mempunyai risiko KET 12 kali lipat ( $R R$ suaian $=11,79 ; 95 \% C I=2,68-51,85)$. Di samping itu terdapat kecenderungan kenaikan risiko $K E T$ dengan lama pemakaian serta jumlah $A K D R$ yang pernah dipakai (tes kecenderungan $P<0,001$ ). Oleh karena itu terhadap wanita hamil yang masih memakai AKDR diperlukan perhatian khusus akan adanya risiko KET yang lebih tinggi.
\end{abstract}

\begin{abstract}
As part of a population-based case-control study in 11 cities in Indonesia in 1989/1990, this study is to assess the risk of ectopic pregnancy (EP) associated with current intrauterine device (IUD) use. The cases were 560 women with EP. The diagnosis was histopathologically confirmed. Each case was matched by one clinically pregnant control who was married, lived in the catchment area and whose age was matched to control by five-year age interval. In-person interviews were conducted to collect information regarding demographic characteristics, past contraceptive use, and obstetrical-gynecological history. Cases and pregnant controls, who at the estimated date of conception were still using IUD were included for analysis. Five hundred and ten cases and 519 pregnant controls were available. Relative to non contraceptive-users, current IUD users who has used IUD for 36-108 months had 14-folds the risk of acquiring EP ladjusted relative risk $(O R)=14.11 ; 95 \%$ confidence interval $(C I)=3.26-61.06$ ], and among women with only one episode of IUD use had II-folds risk of acquiring $E P$ (adjusted $R R=11.79 ; 95 \% C I=2.68-51.85$ ). In addition, there was indication of increasing risk of $E P$ with the number of episodes as well the duration of current IUD use $(P<0.001)$. Therefore, pregnant women who at the estimated date of conception are still using IUD need special attention for a higher risk of acquiring EP.
\end{abstract}

Keywords: no contraceptive, pregnant control

In Indonesia, contraception with an intra uterine device (IUD) is recommended primarily to married women in mutually monogamous relationship. The IUD is one of the most widely used contraceptive methods. According to the Indonesian National Family Planning Coordinating Board there were about 5.3 million women who were using IUD contraceptive.

Some of those women who were using IUDs failed to prevent pregnancy, and had risk of acquiring EP. ${ }^{1-3}$

Department of Community Medicine, Faculty of Medicine, University of Indonesia, Jakarta, Indonesia
The adverse effect of IUD in the form of EP will have a great public health impact, especially to Indonesian family planning program. However, there was no publication on the detail information about the risk of EP, particularly on the number of episodes and duration of current IUD use, among women who were still using IUDs at the estimated date of conception, compared to women who do not use contraceptive method in Indonesia.

Analysis of case-control studies on selected pregnant controls, associated with current IUD use which was still being used at the estimated date of conception, showed increased risk of ectopic pregnancy (EP). 
However, the results varied considerably. ${ }^{2-4}$ The discrepancies of the estimated relative risk of those casecontrol studies were due to the selection of pregnant controls among current IUD users. In addition, there were other bias such as pregnant control setting (hospital, multi hospital, population-based), types of pregnant controls (legal abortion, obstetric, hospital delivery, population delivery), ${ }^{2,3}$ reference group, adjustment for confounding factors, number of subjects, and preference to IUD which could affect the results.,

The objective of this study was to assess the risk of EP associated with the number of episodes and duration of current IUD use at the estimated date of conception, compared to a control group of pregnant married women, who did not use contraceptive method.

\section{METHODS}

This study was part of the population-based case-control study in 11 cities in Indonesia, namely in Medan, Padang, Palembang, Jakarta, Bandung, Semarang, Yogyakarta, Surabaya, Denpasar, Ujungpandang and Manado. Those cities have teaching hospitals which primarily serve defined catchment areas. During the period of 1 April 1989 to 31 August 1990 2,222,000 eligible couples were referred to those hospitals.

Cases were EP that were histopathologically confirmed by histopathologist by the presence of trophoblast, fetal, or chorionic villus tissue in a sample taken at surgery. The women also had to be married, 15 to 44 years of age at diagnosis, and resided within one of the defined catchment areas of the hospitals. Cases were identified by treating physicians and referred to a specially trained nurse-midwife for interview. Interviews were conducted in hospital within the third or fourth day of hospitalization. During the period of the study, 560 eligible cases were identified and all completed the interviews.

In this case-control analysis pregnant controls were used to compare the odds of ectopic nidation between cases and controls, whereas other case-control analysis used non-pregnant controls to compare the odds of pregnancy and subsequent ectopic nidation, between cases and controls. ${ }^{3,5}$

The control groups consisted of married women who lived within the catchment area that was served by the participating hospitals. The control groups were clinically pregnant women of less than 20 -week of pregnancy. The controls were matched to the cases by catchment area and five-year age interval. Each case was matched by one pregnant control.
Controls were randomly selected from the catchment areas of participating hospitals in the following manner. For each area, subdistricts consisting of 40 to 60 -neighborhood were identified, and neighborhoods were randomly selected from this list. Each neighborhood included 20 to 40 eligible women. Eligibility was determined at four-month interval through a door-todoor census. List of potential controls were ordered by age group of five-year intervals $(15-19,20-24,25-29$, $30-34,35-39$, and 40-44 years), by pregnancy, and catchment area. One pregnant control was randomly matched to each case. If a selected control was not available for interview after two return visits to her home, an alternative control was selected.

Control women were interviewed in their homes by a nurse-midwife. Although the interviewers of cases and controls differed, the interviewers were similarly trained specifically for this study. Total of 560 pregnant controls were interviewed.

For cases and pregnant controls, information collected pertained to exposures and characteristics prior to the estimate date of conception. Each woman was asked to report her current method that is, method of birth control at the estimated date conception, the length of time she had been continuously using the last method. the longest duration of using that method, and the total duration of use of that method. Similar information was collected regarding use of each other birth control method that had previously been used. From women who reported ever using an IUD, the following additional information was asked: the last type of IUD used; the duration of the last IUD use; and whether or not symptoms of pelvic inflammatory disease had occurred while using an IUD.

Current users of IUD at the estimated date of conception were defined as those who at least one month before the estimated date of conception were still using IUD.

In order to analyze the failure of IUD contraception and the risk to develop EP, those who were still using IUD, and those who did not use contraceptive method at the estimated date of conception were included for this analysis. Five hundred and ten cases and 519 pregnant controls were available.

A number of risk factors were examined as potential confounders and/or effect modifiers, including: study centers; age (20-24, 25-29, 30-34, 35-39, 40-44 years); education (high $=$ senior high school or above, middle $=$ primary school or junior high school, low = none or 
read only); number of gravidity (none or 1,2, 3 or more); history of mola, tubal surgery, caesarian section, abdomen surgery, appendectomy, prior EP, induced abortion, spontaneous abortion, stillbirth, and pelvic inflammatory disease (PID); other contraceptive use (never/ever); duration of smoking (never, 1-5, 6-10, 11-20 sticks ); duration of current IUD use (none, 1-11 months, 12-23 months, 24-35 months, 36-108 months); number of IUD use episodes (none, 1 time, 2 times or more). Number of gravidity were defined as the total number of live birth, stillbirth, spontaneous abortion, induced abortion, and molar pregnancy. Pelvic inflammatory disease (PID) was defined as a history of treatment for or symptoms of lower abdominal pain and fever.

Unconditional logistic regression analysis ${ }^{6}$ was used in order to control for the confounding effects of risk factors on the relationship between the risk factors and EP.

The results presented include adjustment for the risk factors of known biologic importance ${ }^{7}$ along with those whose presence in a model changed the relative risk (RR) estimate associated with IUD use by more than $10 \%$.

Characteristics that fulfilled the criteria of confounders are included in the analysis by the method of maximum likelihood. Ninety-five percent confidence intervals were based on the standard error of coefficient estimates. Calculation used unconditional logistic methods, and based on candidate of potential risk factors, and the final results were constructed by using Egret software. ${ }^{8}$

Since the cases and controls were most likely to be representative samples for the catchment areas, the relative risk (RR) should be closely appropriated by the odds ratio (OR), ${ }^{7}$ therefore the term relative risk (RR) was used instead of OR throughout the text.

This study was approved by the Ethical Committee of the Indonesian National Family Planning Coordinating Board. Informed consent was obtained from each participant in this study.

\section{RESULTS}

Among cases, the onset of EP ranged from 1 week to 40 weeks of gestational period, and among pregnant controls the gestational period were identified between 2 weeks through 20 weeks. Extracts of medical records revealed that most cases were tubular EP. The cases consisted of 17 cases of intramural or cornual EP (3.3\%), 70 cases of third inner tubular EP (13.7\%), 192 cases of middle third tubular EP (37.7\%), 176 cases of outer third tubular EP (34.5\%), 9 cases of ovarian (1.8\%), 31 cases of tubular abortion or implantation site not identified $(6.1 \%)$, and 15 cases of other EPs $(2.9 \%)$.

Cases and controls were similar in term of centers and age groups. Compared with pregnant controls, cases were more likely to be less educated women, and to have more number of gravidity. Lippes loop IUD was the most IUD type which were being used at the estimated date of conception among cases and controls. None of control used copper T, copper 7, or multiload IUDs. There were 11 cases that reported that they did not know the type of IUD which were still being used at the estimated date of conception (Table 1).

Table 1. Some characteristics of subjects

\begin{tabular}{|c|c|c|c|c|}
\hline \multirow{2}{*}{$x^{2}$} & \multicolumn{2}{|c|}{$\begin{array}{c}\text { Ectopic } \\
\text { pregnancy } \\
(N=510)\end{array}$} & \multicolumn{2}{|c|}{$\begin{array}{l}\text { Pregnant } \\
\text { control } \\
(\mathrm{N}=519)\end{array}$} \\
\hline & n & $\%$ & $n$ & $\%$ \\
\hline \multicolumn{5}{|l|}{ Center } \\
\hline Medan & 57 & 11.2 & 59 & 11.4 \\
\hline Padang & 29 & 5.7 & 28 & 5.4 \\
\hline Palembang & 30 & 5.9 & 25 & 4.8 \\
\hline Jakarta & 116 & 22.7 & 116 & 22.4 \\
\hline Bandung & 63 & 12.4 & 67 & 12.9 \\
\hline Semarang & 25 & 4.9 & 26 & 5.0 \\
\hline Yogyakarta & 38 & 7.5 & 34 & 6.6 \\
\hline Surabaya & 43 & 8.4 & 47 & 9.1 \\
\hline Denpasar & 48 & 9.4 & 52 & 10.0 \\
\hline Ujungpandang & 37 & 7.3 & 38 & 7.3 \\
\hline Manado & 24 & 4.7 & 27 & 5.2 \\
\hline \multicolumn{5}{|l|}{ Age group } \\
\hline $15-19$ years & 12 & 2.4 & 13 & 2.5 \\
\hline 20-24 years & 91 & 17.8 & 93 & 17.9 \\
\hline $25-29$ years & 198 & 38.8 & 202 & 38.9 \\
\hline $30-34$ years & 137 & 26.9 & 138 & 26.6 \\
\hline $35-39$ years & 63 & 12.4 & 65 & 12.5 \\
\hline 40-44 years & 9 & 1.8 & 8 & 1.5 \\
\hline \multicolumn{5}{|l|}{ Education } \\
\hline High school or above & 150 & 29.4 & 172 & 33.1 \\
\hline $\begin{array}{l}\text { Primary or junior high } \\
\text { school }\end{array}$ & 257 & 50.4 & 268 & 51.6 \\
\hline Illiterate or read only & 103 & 20.2 & 79 & 15.2 \\
\hline \multicolumn{5}{|l|}{ Gravidity } \\
\hline 1 & 108 & 21.2 & 242 & 46.6 \\
\hline 2 & 124 & 24.3 & 108 & 19.9 \\
\hline 3 or more & 278 & 54.5 & 174 & 33.5 \\
\hline \multicolumn{5}{|l|}{ IUD type } \\
\hline None & 456 & 89.4 & 506 & 97.5 \\
\hline Lippes loop & 33 & 6.5 & 8 & 1.5 \\
\hline Copper $\mathrm{T}$ & 9 & 1.8 & 5 & 1.0 \\
\hline Copper 7 or Multiload & 1 & 0.2 & 0 & 0 \\
\hline Unknown & 11 & 2.1 & 0 & 0 \\
\hline
\end{tabular}


Table 2 (based on crude relative risks) shows that there were no significant relationship between history of mola, caesarian section, appendectomy, or still birth and EP. However, the risk of EP was increased among those who reported ever had history of tubal surgery, abdomen surgery, previous EP, induced abortion, miscarriage, and PID.

Additionally, based on crude relative risks, there was no significant relationship between EP and history of pill and condom use. On the other hand, history of injectable and natural contraceptive uses seemed to be protecting women against EP. The results of crude relative risks also revealed that compared with those who never smoked, women who ever had smoking habit had increase risk of acquiring EP. According to univariate analysis it seemed that past and current smokers, number of cigarettes smoked, and duration of smoking also increased the risk of EP relative to women who never smoke. Since there was no case whoever used minipill contraception and no control whoever used implant contraception, the calculation of relative risks were not applicable (Table 3 ).

Table 2. History of surgery, obstetry and gynecology, and the risk of ectopic pregnancy

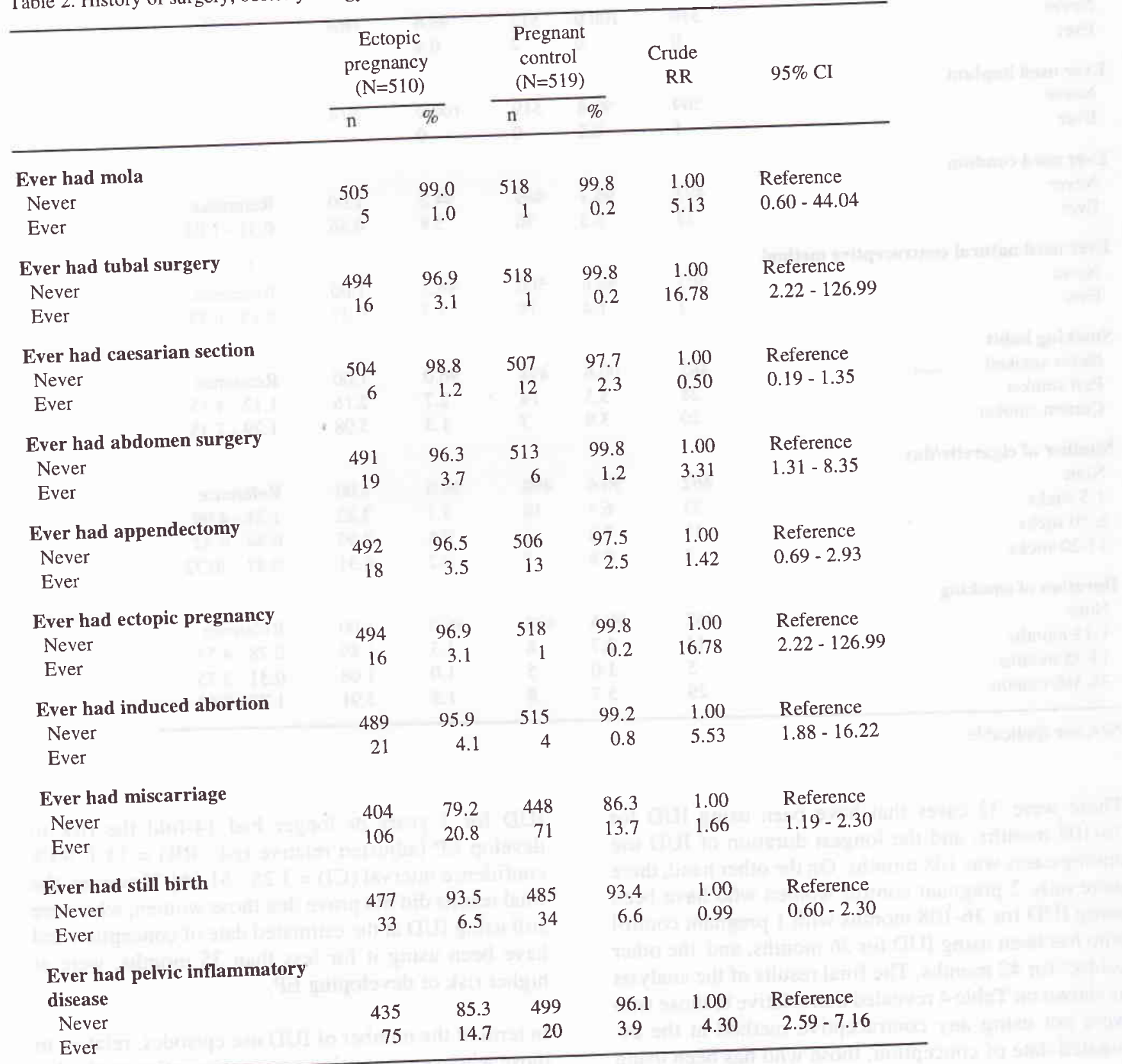


Table 3. Past contraceptive use, smoking habit and the risk of ectopic pregnancy

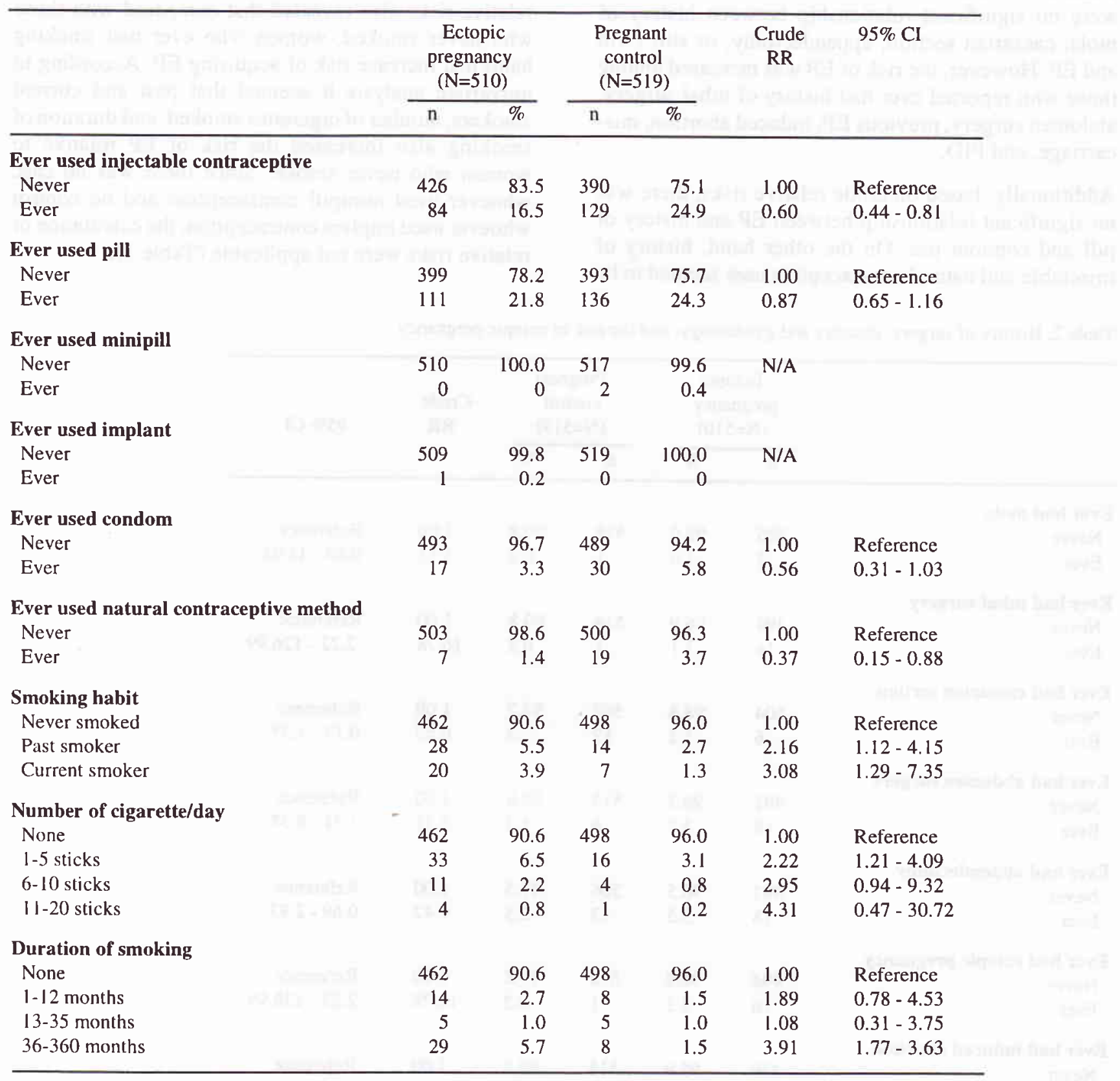

N/A not applicable

There were 32 cases that have been using IUD for 36-108 months, and the longest duration of IUD use among cases was 108 months. On the other hand, there were only 2 pregnant control women who have been using IUD for 36-108 months with 1 pregnant control who has been using IUD for 36 months, and the other subject for 42 months. The final results of the analysis as shown on Table 4 revealed that relative to those who were not using any contraceptive method at the estimated date of conception, those who has been using
IUD for 3 years or longer had 14-fold the risk to develop EP [adjusted relative risk $(\mathrm{RR})=14.1,95 \%$ confidence interval $(\mathrm{CI})=3.26-61.06]$. However, the final results did not prove that those women, who were still using IUD at the estimated date of conception and have been using it for less than 35 months, were at higher risk of developing EP.

In term of the number of IUD use episodes, relative to those who were not using any contraceptive method at 
the estimated date of conception; those who has been using IUD for one episode had 3.8 times increase in the risk to develop EP (adjusted $\mathrm{RR}=3.83 ; 95 \% \mathrm{CI}=$ 1.86 - 7.92), and those who has been using IUD for two on more episodes had 4-fold the risk to develop EP (adjusted $\mathrm{RR}=3.96 ; 95 \% \mathrm{CI}=0.81-19.41 ; P=0.090$ ). In addition, there were trend that duration of current IUD use as well as number of IUD use episodes increased the risk of EP (test for trend $P<0.001$ ). It was also noted that women with only one episode of current IUD use had an increased risk of EP (test for trend $P<0.001)$. The increase was more pronounced (12folds) among women who has been using IUD for three years or more relative to women who did not use any contraception at the estimated date of conception (adjusted $\mathrm{RR}=11.79,95 \% \mathrm{CI}=2.68-51.85)$.

\section{DISCUSSION}

There are several limitations that must be considered in the interpretation of the findings. Firstly, case ascertainment, although based on a defined population, might be incomplete, as some women might have received medical care for their EP at a private hospital which was not included in our study. However, al- though there are private hospitals operating within the study areas, the large majority of EP are treated at the teaching hospitals from which our cases were identified. In addition, we have no data regarding the proportion of the replacements of control.

Cases and controls were interviewed by different individuals. However, all interviewers had the same educational level and were trained in the use of the data collection instrument. We have no data on the last timing of IUD and the other contraceptive methods use that might have interfere with the risk of EP.

In spite of these limitations, the inclusion criteria to our study population which were married gravid women makes our results more directly applicable than those of prior studies. In addition, the pregnant controls of this study were those with less than 20-week pregnancy. By using pregnant controls of less than 20-week pregnancies, it was more likely to have the same probability of finding the IUD in situ as women in the general population. Thereby it was more likely that the controls of this study will represent the proportion of IUD users in the general population. By this means, it would be more likely to minimize the overestimation

Table 4. Number of episodes and duration of current IUD use and the risk of ectopic pregnancy

\begin{tabular}{|c|c|c|c|c|}
\hline & $\begin{array}{c}\text { Ectopic } \\
\text { pregnancy } \\
(\mathrm{N}=510) \\
\end{array}$ & $\begin{array}{c}\text { Pregnant } \\
\text { control } \\
(\mathrm{N}=519)\end{array}$ & $\begin{array}{l}\text { Adjusted } \\
\text { RR* }\end{array}$ & $95 \% \mathrm{CI}$ \\
\hline & $\mathrm{n}$ & $\mathrm{n}$ & & \\
\hline \multicolumn{5}{|c|}{ Duration of current IUD use $†$} \\
\hline None & 456 & 506 & 1.00 & Reference \\
\hline 1-11 months & 5 & 3 & 1.59 & $0.31-8.22$ \\
\hline $12-23$ months & 8 & 3 & 3.09 & $0.70-13.70$ \\
\hline 24-35 months & 9 & 5 & 1.46 & $0.46-4.61$ \\
\hline 36-108 months & 32 & 2 & 14.11 & $3.26-61.06$ \\
\hline \multicolumn{5}{|c|}{ Number of IUD use episodes } \\
\hline None & 456 & 506 & 1.00 & Reference \\
\hline 1 episode & 43 & 11 & 3.83 & $1.86-7.92$ \\
\hline 2 or more episodes & 11 & 2 & 3.96 & $0.81-19.41$ \\
\hline \multicolumn{5}{|c|}{$\begin{array}{l}\text { Duration of current all types of IUD use, } \\
\text { among women with one episode of use } \dagger\end{array}$} \\
\hline None & 456 & 506 & 1.00 & Reference \\
\hline $1-11$ months & 3 & 3 & 1.37 & $0.24-7.72$ \\
\hline $12-23$ months & 5 & 3 & 2.30 & $0.47-11.33$ \\
\hline 24-35 months & 9 & 3 & 2.19 & $0.57-8.44$ \\
\hline $36-108$ months & 26 & 2 & 11.79 & $2.68-51.85$ \\
\hline
\end{tabular}

\footnotetext{
* Adjusted for education level, gravidity, history of pelvic inflammatory disease, previous ectopic pregnancy, ever had abortion, ever use injectable and natural contraceptive methods, and duration of smoking.

$\dagger$ Test for trend $P<0.001$
} 
of the risk of EP. This is due to the fact that control women with a full term pregnancy or delivery are less likely to have an IUD in situ than women in the general population. $^{3,5}$

There was evidence that controls were representative of the general population, as $22.1 \%$ of the total controls interviewed (including those who were excluded from this analysis) reported current use of an IUD. The proportion of IUD users in our controls was similar to overall proportion of IUD users $(22.2 \%)$ among Indonesian women in the area where this study was conducted (this data was obtained from Indonesian National Family Coordinating Board). In addition, pregnant controls were selected randomly from random subsets of neighborhood within the same catchment area as that of cases.

Although the final results of the estimated relative risks were unstable, compared to non contraceptive users, there were indications of increasing risk of $\mathrm{EP}$ with a longer duration of IUD use, increasing number of IUD use episodes, as well as duration of current IUD use among women with only one episode of use (test for trend $P<0.001$ ).

In term of duration of current IUD use, among all women (with one, two or more episodes) relative to women without contraceptive, the final results indicate that women who have been using IUD for three years or longer around the time of conception had a more pronounced (14-folds) increase in the risk of developing EP. Among women who have been using IUD for three years or longer, the increased risk was also noted on whom with only one episode of IUD use (12-folds). The similar results between women who have been using IUDs for one episode and more episodes were most likely due to the small number of women who ever used IUDs for two or more episodes (11 cases and 2 pregnant controls).

In this analysis, it was not able to calculate the increased risk of EP among women with 2 or more episodes of IUD use with the same intervals of duration of IUD use as women with only one episode, because there was no case who has been using IUD for 24-35 months and 36 months or longer, and all pregnant controls ( 2 subjects) have been using IUD for 36-108 months. In addition, it was not able to calculate the risk of EP on IUD types since there were 11 cases who reported that they did not know the type of IUD used at the estimated time of conception. In addition, it was not able to analyze the risk of current IUD use among the subgroup of 48 months or more, because the longest duration of IUD use among pregnant controls was 42 months.

The previous publications ${ }^{3,9-13}$ showed that current IUD users, relative to pregnant women without contraceptive or women who did not use IUD at the estimated date of conception, had increased risk of EP.

There was a meta-analysis study, ${ }^{3}$ that was based on publications of selected case-control studies using pregnant women as controls between 1977 and 1994, on the risk of EP on current IUD users. The results of the meta-analysis without indicating the duration of IUD use showed that EP risk was markedly increased in conceptions with IUD in situ (pooled $\mathrm{OR}=10.63$; $95 \% \mathrm{CI}=7.66-14.74$ ). The odds ratios range from 5.7 to 48.2 .

The final results of this analysis on the relationship between the number of episodes and duration of current IUD use and the risk of EP showed that there were other risk factors that contributed to the risk of EP. These risk factors were history of PID, prior ectopic pregnancy, prior abortion, a bigger number of gravidity, lower education level, and longer duration of smoking. While the use of injectable and natural contraceptive methods were protecting the women of acquiring EP.

The contributing risk factors for EP taken into account on this analysis were also detected in the other publications. PID was noted to be a risk factor for EP by some authors, ${ }^{9-12}$ while prior EP was noted to be related to EP on the $\mathrm{WHO}^{9}$ paper and by Marchbank et al. ${ }^{11}$ Prior abortion was noted by other publications, ${ }^{10,12}$ while smoking was noted by some authors. $2,9,11,13$

The current data revealed that among the cases, the earliest onset of symptoms of EP was at one week of pregnancy, and the longest was at 40 weeks. This suggests that the onset of symptoms of EP might happen at an early stage of pregnancy until gestational terms. Since EP is life threatening, early diagnosis and prompt treatment is needed. In order to perform early diagnosis and prompt treatment of EP, current diagnostic methods such as ultrasonography, human chorionic gonadotropin (hCG), vaginal transducers and other techniques allow and improve the possibilities of early diagnosis of EP, even before the onset of any symptoms.

In conclusion, beside the other risk factors which contribute in increasing the risk of EP, any pregnant 
woman who were still using IUD at the date of estimated conception, especially those who have been using IUD for more than 36 months should be properly informed of the high risk of EP. They also should receive early diagnosis and prompt treatment of EP, that can improve the prospects for the patients.

\section{Acknowledgment}

The author thanks Dr. Olav Meirik (Special Program of Research, Development and Research Training in Human Reproduction, World Health Organization) and Dr. Sujana Jatiputera (School of Public Health University of Indonesia) for technical assistance in the preparation of the study. Special thanks are extended to Dr. Mary Anne Rossing (Fred Hutchinson Cancer Research Center, Seattle USA) for data verification and transformation of the study. Special thanks to colleagues in 11 centers in Indonesia for their high dedication in participating in the study, and also for the subjects who voluntarily and cooperatively participated in this study. Lastly to Dr. Abdul Bari Saifuddin and Dr. Isnani A. Suryono to review earlier drafts of this manuscript that improved the final product.

\section{REFERENCES}

1. World Health Organization. Mechanism of action, safety and efficacy of intrauterine devices: Report of a WHO Scientific Group. In: Technical Report Series 753. Geneva: World Health Organization, 1987;1-91.

2. Chow WH, Daling JR, Cates W, Greenberg RS. Epidemiology of ectopic pregnancy. Epidemiol Review 1987;9:70-88.
3. Xiong $X$, Buekens $P$, Wollast E. IUD use and the risk of ectopic pregnancy: A meta-analysis of case-control studies. Contraception 1995;52:23-34.

4. Mol BJW, Ankum WM, Bossuyt PM, Veen vD. Contraception and the risk of ectopic pregnancy. Contraception 1995;52:337-41.

5. Weiss NS, Daling JR, Chow WH. Control definition in case-control studies of ectopic pregnancy. AJPH 1985; 75:67-8

6. Breslow NE, Day NE. Statistical methods in cancer research. Vol I. The analysis of case-control studies. IARC Scientific Pub. No.32. Lyon: Intemational Agency for Research on Cancer, 1980.

7. Hosmer DW, Lemeshow S. Applied logistic regression. New York: John Willey \& Sons, 1989.

8. Statistics and Epidemiology Research Corporation. Egret: Reference manual. Seattle: The corporation, 1990.

9. World Health Organization. Task Force on Intrauterine Devices for Fertility Regulation. A multi-national case-control study of ectopic pregnancy. Clin Reprod Fertil 1986;3:131-4.

10. Thorbum JO, Philipson M, Lindblom B. Background factors of ectopic pregnancy II: Risk estimation by mean of logistic model. Eur J Obstet; 1986:333-40.

11. Marchbank PA, Annegers JF, Coulam CB, Strathy JH, Kurland LT. Risk factors for ectopic pregnancy. A populationbased study. JAMA 1988;259:1823-7.

12. Chow JM, Yonekura ML, Richwald GA, Greenland S, Sweet RL, Schachter J. The association between Chlamydia trachomatis and ectopic pregnancy. JAMA 1990; 263: 3164-7.

13. Kalandidi A, Doulgerakis M, Tzonou A, Hsieh CC, Aravandinos D, Trichopoulos D. Induced abortions, contraceptive practices, and tobacco smoking as risk factors for ectopic pregnancy in Athens, Greece. Br J Obstet Gynecol 1991:98:207-13. 